\title{
EVALUASI DAYA LAYAN FASILITAS PENDIDIKAN DI KOTA BLITAR
}

\author{
Ersza Triyoga Asmaradhana1, Agus Purnomo ${ }^{2 *}$ Idris $^{3}$ \\ 1,2,3Program Studi Pendidikan Ilmu Pengetahuan Sosial, Fakultas Ilmu Sosial, Universitas Negeri Malang, Malang, Indonesia \\ *Email Koresponden: agus.purnomo.fis@um.ac.id
}

Diterima: 25-02-2021, Revisi: 09-05-2021, Disetujui: 07-06-2021

(C)2021 Program Studi Pendidikan Geografi, FISE, Universitas Hamzanwadi

\begin{abstract}
Abstrak Salah satu masalah pendidikan adalah kesenjangan fasilitas pendidikan dengan jumlah penduduk yang harus dilayani. Permasalahan ini muncul karena aspek keterjangkauan fasilitas. Evaluasi daya layan fasilitas pendidikan Kota Blitar penting dilakukan karena data yang ada masih belum menggambarkan secara detail terkait jumlah ketersediaan fasilitas pendidikan di tiap kecamatan dan belum menggambarkan daya layan fasilitas pendidikan yang ada. Tujuan artikel ini adalah mengevaluasi daya layan fasilitas pendidikan pada SD, SMP, dan SMA di Kota Blitar, serta proyeksi kebutuhan pada tahun 2030. Pendekatan yang digunakan adalah kuantitatif dengan metode sensus cross sectional. Data yang digunakan sebagai dasar analisis berasal dari data sekunder tentang jumlah dan lokasi fasilitas pendidikan. Data dianalisis menggunakan analisis daya layan dan proyeksi kebutuhan fasilitas berdasarkan laju pertumbuhan penduduk. Hasil temuan menunjukkan bahwa daya layan fasilitas pendidikan yang surplus hanya SMP sederajat dan SMA sederajat di Kota Blitar hanya di Kecamatan Kepanjenkidul. Proyeksi kebutuhan fasilitas SD sederajat hingga SMA sederajat pada tahun 2030 di Kota Blitar masih diperlukan penambahan fasilitas, kecuali fasilitas pendidikan SMP sederajat dan SMA sederajat di Kecamatan Kepanjenkidul yang tidak membutuhkan tambahan fasilitas.
\end{abstract}

Kata kunci: daya layan, fasilitas pendidikan, proyeksi kebutuhan

\begin{abstract}
One of the problems of education is the gap between educational facilities and the number of people that must be served. This problem arises because of the affordability aspect of the facility. Evaluation southwest serviceability amenities education Blitar City is important to do because the data that there is still not describe in detail related to the number the availability of facilities of education in each sub-district and not illustrate power intellectually facilities of education that exist. The purpose articles of this is to evaluate the power service life of the facility of education at the elementary, middle, and high schools in Blitar, as well as the projection of needs in the year 2030. The approach that is used is quantitative with cross sectional census method. The data used as the basis for the analysis comes from secondary data on the number and location of educational facilities. Data were analyzed using analysis of power serviceability and projected needs of the facility based on the rate of growth of the population. The results of the findings indicates that power service life of the facility of education that surplus only junior equal and high school equivalent in Blitar City only in the District Kepanjenkidul. Projected needs facilities SD equivalent to high school or equivalent in the year 2030 in the Blitar City still needed additional facilities, except facilities of education junior equal and high school equivalent in the District Kepanjenkidul which does not require additional facilities.
\end{abstract}

Keywords: serviceability, educational facilities, projected needs

\section{PENDAHULUAN}

Pendidikan merupakan salah satu kebutuhan bagi manusia dan suatu aspek yang berperan sangat penting untuk perkembangan kehidupan manusia. Hal itu tidak bisa dipungkiri bahwa sejumlah populasi manusia di setiap tempat pasti akan membutuhkan pendidikan (Nurlaela, 2014). Pendidikan merupakan sarana yang strategis untuk meningkatkan kualitas manusia. Artinya dengan adanya pendidikan kualitas manusia bisa ditingkatkan (Adniyah \& Putra, 2017). Rendahnya mutu pendidikan menjadi permasalahan yang dihadapi oleh pemerintah Indonesia (Latief, Rohmat, \& Ningrum, 2014). Salah satu faktor keberhasilan program pendidikan dipengaruhi oleh faktor sarana dan prasarana, yang 
mana pengelolaan serta pemanfaatannya harus dilakukan dengan optimal (Suryani, 2017). Fasilitas pendidikan merupakan salah satu aspek utama yang harus diperhatikan oleh setiap pengelola pendidikan di setiap daerah. Fasilitas pendidikan yang memadai atau mencukupi terkadang tidak terimbangi oleh jumlah penduduk yang ada di suatu wilayah. Berdasarkan RPJMN 2015-2019, Tantangan pembangunan pendidikan salah satunya adalah adanya kesenjangan pendidikan yaitu antar jenis kelamin, kelompok sosial dan ekonomi serta antar wilayah (BPS, 2019).

Fasilitas pendidikan yang kurang memadai menjadikan salah satu masalah pendidikan di Indonesia. Kurangnya fasilitas pendidikan merupakan salah satu hal mendasar penyebab terjadinya kesenjangan pendidikan yang ada di Indonesia (Prianto \& Putri, 2017). Studi pendahuluan membuktikan bahwa masih banyak daerah di Indonesia yang mengalami kasus kekurangan fasilitas pendidikan (Ramadhana \& Prakoso, 2018; Junianto \& Lumbantoruan, 2013; Baroroh \& Kurniawan, 2018). Studi ini dilakukan di berbagai wilayah, seperti perkotaan, kabupaten, dan wilayah hasil pemekaran. Hasil dari penelitian tersebut didapatkan bahwa masih adanya kekurangan fasilitas pendidikan di berbagai wilayah Indonesia. Oleh karena itu, jika penyediaan fasilitas pendidikan memadahi terhadap masyarakat, maka pendidikan dapat berjalan dengan baik sehingga seseorang dapat berkembang dengan maksimal baik secara sosial maupun ekonomi (Umasangadji, 2015).

Salah satu permasalahan pada pendidikan bukan hanya kesenjangan pendidikan saja, akan tetapi juga keterjangkauan atau daya layannya. Di Provinsi Jawa Timur, salah satu kota yang mana setidaknya mampu menyediakan pemenuhan kebutuhan fasilitas pendidikan yang mendukung adalah Kota Blitar. Berdasarkan BPS Kota Blitar (2020) hanya menerangkan jumlah peserta didik dan jumlah fasilitas pendidikan secara keseluruhan di Kota Blitar. Data BPS Kota Blitar 2020 tersebut masih belum sinkron secara resmi pada data jumlah fasilitas pendidikan di Kemdikbud. Terkait fasilitas pendidikan di Kota Blitar masih belum menggambarkan secara detail terkait jumlah ketersediaan di tiap kecamatan yang ada di Kota Blitar dan belum menggambarkan daya layan fasilitas pendidikan yang ada.

Penyediaan fasilitas pendidikan di Kota Blitar merupakan salah satu aspek yang sangat penting, hal ini dikarenakan instrumen pendukung dalam dunia pendidikan yaitu fasilitas pendidikan yang juga berperan guna mendukung kegiatan belajar mengajar. Fasilitas pendidikan yang belum bisa sepenuhnya melayani masyarakat akan mengakibatkan kualitas masyarakat atau penduduk di sekitarnya akan tertinggal. Kualitas masyarakat yang tertinggal akan memberikan dampak yang mengakibatkan bertambahnya angka putus sekolah. Menurut Badan Pusat Statistik, penyebab anak hingga putus sekolah dikarenakan kurang menguntungkannya keadaan geografis di wilayah tersebut dan akses yang terbatas untuk pergi ke sekolah karena jarak ke sekolah jauh atau kurangnya fasilitas pendidikan (BPS, 2015). Seperti halnya jarak yang jauh antar tempat tinggal dengan sekolah akan menimbulkan minat dan anak untuk bersekolah menurun. Oleh karena itu, ketersediaan fasilitas pendidikan di suatu wilayah sangatlah penting untuk mendukung proses kegiatan belajar dan mengajar. Hal ini bertujuan untuk penyelenggaraan pendidikan dan memberikan kemudahan untuk guru, siswa ataupun tenaga kependidikan (Ningsih, Ernawati, \& Nofrion, 2018). Hal tersebut nantinya dapat mengembangkan dan meningkatkan kualitas pendidikan.

Selain itu juga, fasilitas pendidikan yang belum merata juga akan mengakibatkan mengurangi kemampuan daya layan fasilitas pendidikan terhadap masyarakat yang ada di Kota Blitar. Untuk itulah ketersediaan fasilitas pendidikan yang memadai sangatlah penting untuk daya layan bagi masyarakat agar mereka dapat hidup dengan baik karena ketersediaan fasilitas pendidikan guna mendapatkan ilmu pengetahuan. Penyediaan dan keterjangkauan fasilitas pendidikan apabila memadai terhadap masyarakat, maka pendidikan dapat berjalan dengan baik sehingga seseorang dapat berkembang dengan maksimal baik secara sosial maupun ekonomi (Umasangadji, 2015). Hal ini maka dapat disimpulkan bahwa dengan adanya daya layan fasilitas pendidikan, nantinya diharapkan dapat mengembangkan kualitas pendidikan yang mana akan berdampak untuk kualitas sumber daya manusia (SDM) serta sebagai pertimbangan dalam perencanaan masa yang akan datang (Gewab, Malik, \& Karongkong, 2015).

Merujuk pada studi terdahulu bahwa pelayanan fasilitas pendidikan belum mencukupi, artinya di suatu wilayah ketersediaan fasilitas pendidikan yang ada belum sepenuhnya mampu memenuhi dan mencukupi kebutuhan (Henlita \& Handayeni, 2013; Baroroh \& Kurniawan, 2018; Uang, Rengkung, \& Sembel, 2017). Penelitian terdahulu dilakukan di beberapa lokasi yaitu, 1) Kabupaten Sidoarjo, 2) 
Kabupaten Pringsewu Provinsi Lampung, 3) Kecamatan Mapanget Kota Manado. Penelitian ini berupaya untuk mengisi celah informasi mengenai kemampuan daya layan fasilitas pendidikan yang tersedia di Kota Blitar untuk meningkatkan kualitas pendidikan secara optimal. Berdasarkan hal itu, pada penelitian ini akan mengkaji daya layan fasilitas pendidikan negeri dan swasta pada jenjang pendidikan dasar dan menengah yaitu SD sederajat, SMP sederajat, SMA sederajat di Kota Blitar. Oleh karena itu, perlu adanya perhatian terkait fasilitas pendidikan di Kota Blitar, dengan tujuan: 1) Menganalisis daya layan fasilitas pendidikan pada jenjang dasar dan menengah di Kota Blitar; dan 2) Proyeksi kebutuhan fasilitas pendidikan di Kota Blitar tahun 2030.

\section{METODE PENELITIAN}

Penelitian ini menggunakan pendekatan kuantitatif dengan metode sensus. Pendekatan kuantitatif adalah salah satu pendekatan penelitian dengan menggunakan instrumen penelitian yang bertujuan untuk meneliti populasi atau sampel (Sugiyono, 2017). Metode sensus adalah seluruh anggota dari populasi digunakan sebagai data penelitian (Ibrahim, 2020). Sensus dilakukan untuk mengumpulkan informasi terkait jumlah semua fasilitas pendidikan baik negeri dan swasta yang mencakup SD sederajat, SMP sederajat dan SMA sederajat di Kota Blitar. Rangkaian penelitian dideskripsikan dalam diagram alir pada Gambar 1.

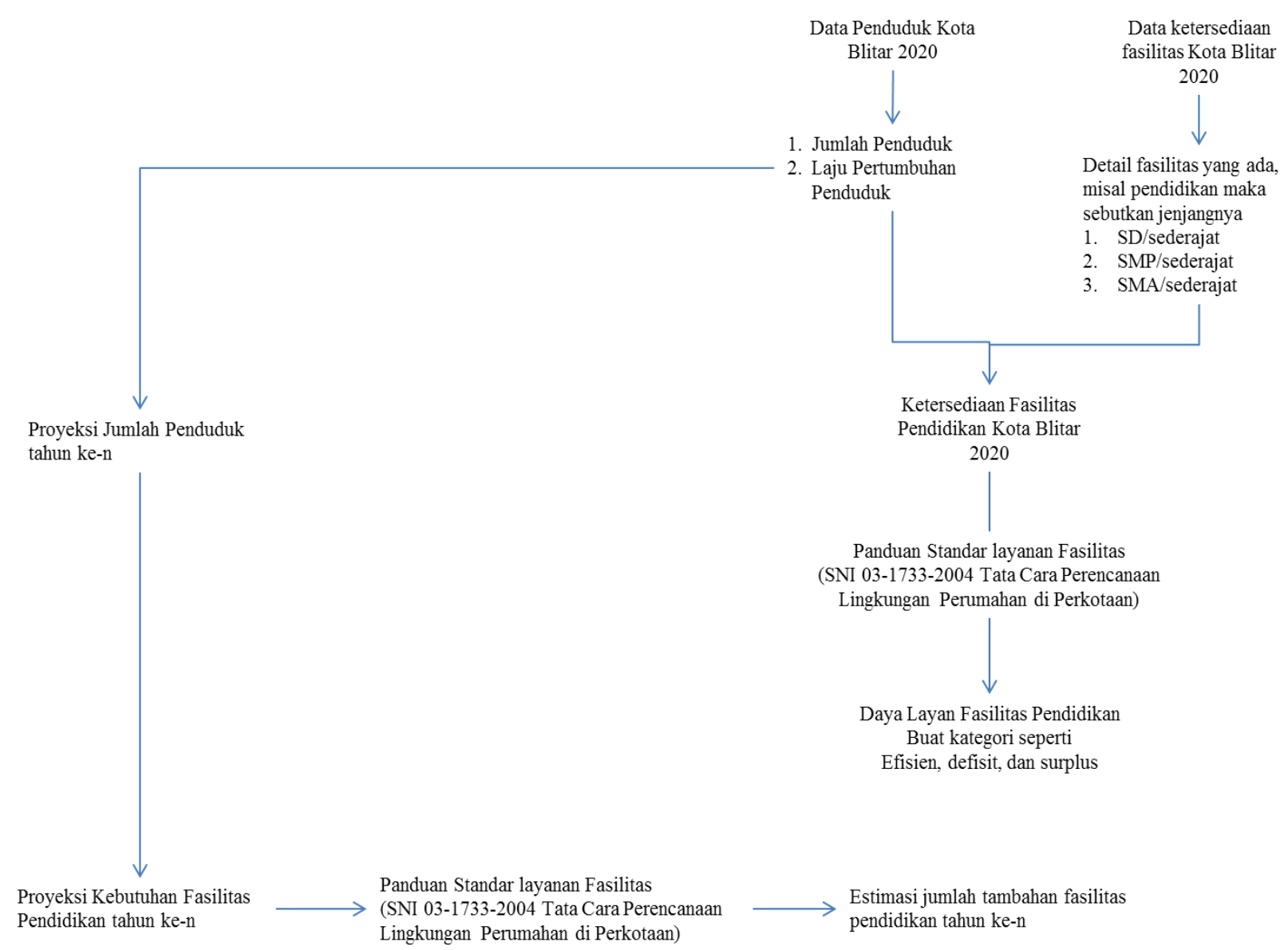

Gambar 1. Diagram Alir Penelitian

(Sumber: Peneliti, 2021)

Populasi merupakan seluruh karakteristik yang dimiliki oleh subjek maupun objek yang telah ditentukan untuk dipelajari yang selanjutnya bisa ditarik kesimpulan oleh peneliti (Sugiyono, 2017). Populasi dari penelitian ini adalah fasilitas pendidikan negeri dan swasta yaitu jenjang SD sederajat, SMP sederajat, SMA sederajat di Kota Blitar. Sampel merupakan bagian dari karakteristik dan jumlah populasi (Sugiyono, 2017). Teknik sampling yang digunakan di penelitian ini adalah saturated sampling atau sampel jenuh. Sampel pada penelitian ini adalah Kecamatan Sukorejo, Kepanjenkidul, dan 
Sananwetan di Kota Blitar. Data yang diperoleh dalam penelitian adalah data sekunder. Data sekunder yaitu data yang didapatkan dan dikumpulkan dari berbagai macam sumber yang sudah ada oleh peneliti (Siyoto \& Sodik, 2015). Data sekunder berupa jumlah fasilitas pendidikan negeri dan swasta pada jenjang SD sederajat, SMP sederajat, SMA sederajat yang diperoleh dari data kemdikbud dan jumlah penduduk di Kota Blitar tahun 2020 serta laju pertumbuhan penduduk Kota Blitar yang diperoleh dari BPS Kota Blitar dalam angka 2020.

Teknik analisis yang digunakan dalam penelitian ini adalah analisis daya layan dan proyeksi kebutuhan fasilitas 2030. Daya layan merupakan perhitungan antara jumlah ketersediaan fasilitas pendidikan dengan membandingkan jumlah penduduk secara keseluruhan dan dengan pembanding standar. Apabila nilai dari daya layan melebihi dari standar pelayanan minimal yang ditetapkan yaitu SNI 03-1733-2004 Tentang Tata Cara Perencanaan Lingkungan Perumahan di Perkotaan (Tabel 1), maka kondisi daya layannya juga akan lebih baik.

Rumus daya layan (Muta'ali, 2015)

Daya layan tiap jenis fasilitas $=\frac{\text { Jumlah tiap jenis fasilitas yang ada }}{\text { Jumlah tiap jenis fasilitas minimum }}$

Jumlah tiap jenis fasilitas minimum $=\frac{\text { Jumlah Penduduk per Kecamatan }}{\text { Standar Minimal Fasilitas Pendidikan }}$

Berdasarkan rumus tersebut, hasil daya layan dapat diklasifikasikan sebagai berikut.

Jika DL $=1$, terjadi keseimbangan antara kebutuhan penduduk dengan keberadaan fasilitas (efisien).

Jika DL > 1, keberadaan fasilitas yang ada telah mampu mendukung kebutuhan penduduk, dan dapat ditafsirkan tingkat pelayanan mencukupi (surplus).

Jika DL $<1$, keberadaan fasilitas belum mampu mendukung kebutuhan penduduk, atau terjadi kekurangan fasilitas (defisit).

Perkiraan kebutuhan fasilitas pelayanan tergantung dari jumlah penduduk yang ada, oleh sebab itu data jumlah penduduk di suatu wilayah yang akan dikaji sangat dibutuhkan untuk diproyeksikan pada tahun-tahun yang akan datang, sehingga pertambahan jumlah penduduk akan diperlukan untuk perhitungan proyeksi kebutuhan fasilitas (Tahir \& Nahdatunnisa, 2020). Proyeksi penduduk dan SNI 03-1733-2004 tentang tata cara perencanaan lingkungan perumahan di perkotaan merupakan acuan untuk memproyeksikan kebutuhan fasilitas. Hasil analisis pertumbuhan penduduk ini, kemudian digunakan sebagai dasar perhitungan kebutuhan fasilitas pelayanan, untuk memperoleh hasil kebutuhan fasilitas dalam 10 tahun mendatang maka formula yang digunakan pada metode ini adalah proyeksi geometrik.

Rumus geometrik (Muta'ali, 2015)

$\mathrm{Pt}=\mathrm{Po}(1+\mathrm{r}) \mathrm{t}$

Keterangan:

$\mathrm{Pt}=$ Penduduk pada tahun $\mathrm{n}$

Po $=$ Penduduk pada tahun $n$

$\mathrm{r}=$ Angka pertumbuhan penduduk $(\%)$

$\mathrm{t}=$ Waktu dalam tahun

Rumus proyeksi kebutuhan fasilitas.

$\operatorname{Di}-\mathrm{t}(\mathrm{n})=\operatorname{JPt}(\mathrm{n}) /$ Thi 
Keterangan:

$\mathrm{JPt}(\mathrm{n})=$ Jumlah penduduk hasil proyeksi pada tahun ke-n

Thi $=$ Threshold (SNI 03-1733-2004 tentang tata cara perencanaan lingkungan perumahan di perkotaan)

Berdasarkan rumus di atas maka dapat dihitung Jumlah Tambahan Fasilitas (JTF) pelayanan yang harus dipenuhi pada tahun ke-n.

$\mathrm{JTF}=\operatorname{Di}-\mathrm{t}(\mathrm{n})-\mathrm{Si}$

Keterangan:

$\mathrm{JTF}=$ Proyeksi tambahan fasilitas

Di-t $(\mathrm{n})=$ Kebutuhan sarana pendidikan pada tahun proyeksi

$\mathrm{Si}=$ Ketersediaan sarana pendidikan

Tabel 1. Kriteria Penentuan Fasilitas Pelayanan Pendidikan

\begin{tabular}{ccc}
\hline No. & Fasilitas yang disediakan & Jumlah Minimum Penduduk Pendukung \\
\hline 1 & Sekolah Dasar & 1600 \\
2 & Sekolah Lanjutan Tingkat Pertama & 4800 \\
3 & Sekolah Lanjutan Tingkat Atas & 4800 \\
\hline
\end{tabular}

Sumber: SNI 03-1733-2004 Tata Cara Perencanaan Lingkungan Perumahan di Perkotaan

\section{TEMUAN DAN PEMBAHASAN}

\section{Daya Layan Fasilitas Pendidikan di Kota Blitar}

Indikator penting sebagai penunjang pendidikan salah satunya adalah ketersediaan fasilitas. Fasilitas pendidikan jenjang SD sederajat, SMP sederajat, dan SMA sederajat di Kota Blitar telah dimiliki oleh tiga kecamatan, yaitu Kecamatan Sukorejo, Kepanjenkidul, dan Sananwetan. Jumlah fasilitas pendidikan yang tersedia di Kecamatan Sukorejo yaitu 23 unit SD sederajat, 6 unit SMP sederajat, dan 7 SMA sederajat. Jumlah fasilitas pendidikan di Kecamatan Kepanjenkidul adalah 24 unit SD sederajat, 10 unit SMP sederajat, dan 12 unit SMA sederajat, sedangkan di Kecamatan Sananwetan jumlah fasilitas pendidikan yang tersedia adalah 26 unit SD sederajat, 10 unit SMP sederajat, dan 11 unit SMA sederajat. Tersedianya fasilitas pendidikan tersebut proses kegiatan belajar dan mengajar akan terlaksana dengan baik. Menurut Inkiriwang, Singal, \& Roeroe (2020) apabila semua aspek yang terkait dengan pendidikan terpenuhi, maka kegiatan pendidikan dapat berjalan dengan lancar, salah satunya adanya fasilitas pendidikan. Oleh karena itu, dengan tersedianya fasilitas pendidikan SD sederajat hingga SMA sederajat di tiga Kecamatan Kota Blitar, nantinya dapat meningkatkan kualitas pendidikan (Olilingo, 2017).

Tabel 2. Daya Layan Fasilitas Pendidikan SD sederajat di Kota Blitar

\begin{tabular}{|c|c|c|c|c|c|c|c|}
\hline \multirow{4}{*}{ Kecamatan } & \multicolumn{7}{|c|}{ Fasilitas SD sederajat Tahun 2020} \\
\hline & $\begin{array}{l}\text { Jumlah } \\
\text { Penduduk }\end{array}$ & $\begin{array}{c}\text { SPM } \\
\text { (Penduduk } \\
\text { Pendukung) }\end{array}$ & $\begin{array}{c}\text { Jumlah SD } \\
\text { sederajat } \\
\text { tersedia }\end{array}$ & $\begin{array}{l}\text { Jumlah SD } \\
\text { sederajat } \\
\text { Minimum }\end{array}$ & $\begin{array}{c}\text { Nilai Daya } \\
\text { Layan }\end{array}$ & $\begin{array}{c}\text { Klasifikasi } \\
\text { Daya }\end{array}$ & $\begin{array}{c}\text { Penamba } \\
\text { han SD }\end{array}$ \\
\hline & $\begin{array}{c}\text { data } \\
\text { sekunder }\end{array}$ & pedoman & $\begin{array}{c}\text { data } \\
\text { sekunder }\end{array}$ & $\begin{array}{c}\text { pengolahan } \\
\text { data }\end{array}$ & $\begin{array}{l}\text { pengolaha } \\
\text { n data }\end{array}$ & Layan & sederajat \\
\hline & 1 & 2 & 3 & $4=1: 2$ & $5=3: 4$ & 6 & 7 \\
\hline Sukorejo & 53882 & 1600 & 23 & 34 & 0.68 & Defisit & 11 \\
\hline Kepanjenkidul & 45395 & 1600 & 24 & 28 & 0.85 & Defisit & 4 \\
\hline Sananwetan & 58632 & 1600 & 26 & 37 & 0.71 & Defisit & 11 \\
\hline
\end{tabular}

Sumber: hasil analisis peneliti, 2021. 
Tabel 3. Daya Layan Fasilitas Pendidikan SMP sederajat di Kota Blitar

\begin{tabular}{|c|c|c|c|c|c|c|c|}
\hline \multirow{4}{*}{ Kecamatan } & \multicolumn{7}{|c|}{ Fasilitas SMP sederajat Tahun 2020} \\
\hline & $\begin{array}{l}\text { Jumlah } \\
\text { Penduduk }\end{array}$ & $\begin{array}{c}\text { SPM } \\
\text { (Penduduk } \\
\text { Pendukung) }\end{array}$ & $\begin{array}{c}\text { Jumlah SMP } \\
\text { sederajat } \\
\text { tersedia }\end{array}$ & $\begin{array}{c}\text { Jumlah SMP } \\
\text { sederajat } \\
\text { Minimum }\end{array}$ & $\begin{array}{l}\text { Nilai Daya } \\
\text { Layan }\end{array}$ & $\begin{array}{c}\text { Klasifikasi } \\
\text { Daya }\end{array}$ & $\begin{array}{l}\text { Penamba } \\
\text { han SMP }\end{array}$ \\
\hline & $\begin{array}{c}\text { data } \\
\text { sekunder }\end{array}$ & pedoman & data sekunder & $\begin{array}{c}\text { pengolahan } \\
\text { data }\end{array}$ & $\begin{array}{c}\text { pengolaha } \\
\text { n data }\end{array}$ & Layan & sederajat \\
\hline & 1 & 2 & 3 & $4=1: 2$ & $5=3: 4$ & 6 & 7 \\
\hline Sukorejo & 53882 & 4800 & 6 & 11 & 0.53 & Defisit & 5 \\
\hline Kepanjenkidul & 45395 & 4800 & 10 & 9 & 1.06 & Surplus & -1 \\
\hline Sananwetan & 58632 & 4800 & 10 & 12 & 0.82 & Defisit & 2 \\
\hline
\end{tabular}

Sumber: hasil analisis peneliti, 2021.

Tabel 4. Daya Layan Fasilitas Pendidikan SMA sederajat di Kota Blitar

\begin{tabular}{|c|c|c|c|c|c|c|c|}
\hline \multirow{4}{*}{ Kecamatan } & \multicolumn{7}{|c|}{ Fasilitas SMA sederajat Tahun 2020} \\
\hline & $\begin{array}{l}\text { Jumlah } \\
\text { Penduduk }\end{array}$ & $\begin{array}{c}\text { SPM } \\
\text { (Penduduk } \\
\text { Pendukung) }\end{array}$ & $\begin{array}{c}\text { Jumlah SMA } \\
\text { sederajat } \\
\text { tersedia }\end{array}$ & $\begin{array}{c}\text { Jumlah SMA } \\
\text { sederajat } \\
\text { Minimum }\end{array}$ & $\begin{array}{l}\text { Nilai Daya } \\
\text { Layan }\end{array}$ & $\begin{array}{c}\text { Klasifikasi } \\
\text { Daya }\end{array}$ & $\begin{array}{l}\text { Penamba } \\
\text { han SMA }\end{array}$ \\
\hline & $\begin{array}{c}\text { data } \\
\text { sekunder }\end{array}$ & pedoman & data sekunder & $\begin{array}{l}\text { pengolahan } \\
\text { data }\end{array}$ & $\begin{array}{c}\text { pengolaha } \\
\mathrm{n} \text { data }\end{array}$ & Layan & sederajat \\
\hline & 1 & 2 & 3 & $4=1: 2$ & $5=3: 4$ & 6 & 7 \\
\hline Sukorejo & 53882 & 4800 & 7 & 11 & 0.62 & Defisit & 4 \\
\hline Kepanjenkidul & 45395 & 4800 & 12 & 9 & 1.27 & Surplus & -3 \\
\hline Sananwetan & 58632 & 4800 & 11 & 12 & 0.90 & Defisit & 1 \\
\hline
\end{tabular}

Sumber: hasil analisis peneliti, 2021.

Nilai daya layan fasilitas pendidikan SD sederajat, SMP sederajat, dan SMA sederajat di Kota Blitar berdasarkan tabel 2, 3, dan 4 yang tingkat pelayanannya defisit berada di Kecamatan Sukorejo dan Kecamatan Sananwetan, sedangkan Nilai daya layan fasilitas pendidikan yang tingkat pelayanannya defisit di Kecamatan Kepanjenkidul hanya fasilitas pendidikan SD sederajat. Nilai daya layan tersebut memiliki tingkat pelayanan defisit karena nilai kurang dari satu $(\mathrm{DL}<1)$. Nilai daya layan kurang dari satu (DL < 1) akan dikatakan tingkat pelayanannya defisit karena jumlah fasilitas yang tersedia belum mampu mendukung kebutuhan penduduk atau terjadi kekurangan fasilitas (Muta'ali, 2015). Penduduk yang belum terlayani oleh fasilitas pendidikan nantinya akan mencari sekolah di luar wilayahnya. Hal tersebut didukung oleh teori lokasi (Tarigan, 2006) terkait aksesibilitas yaitu kemudahan dalam mencapai suatu lokasi ditinjau dari lokasi di sekitarnya. Hal ini juga sesuai dengan Uang, Rengkung, \& Sembel (2017) wilayah yang tidak terlayani fasilitas pendidikan, maka penduduk bisa memilih sekolah di luar permukimannya dan mengakibatkan kurangnya pemerataan.

Ketidakmerataan fasilitas pendidikan tersebut akan menyebabkan fasilitas pendidikan masih belum mampu melayani kebutuhan pada jumlah penduduk yang ada jika dibandingkan dengan standar pelayanan, yang mana jumlah penduduk merupakan penentu terkait adanya fasilitas pelayanan. Hal tersebut didukung dengan Sadali, Intizhar, \& Aisyah (2017) ketersediaan fasilitas di suatu wilayah perlu disesuaikan dengan standar kebutuhan untuk melayani penduduk yang berada pada wilayah tersebut. Oleh karena itu, daya layan fasilitas pendidikan yang defisit nantinya diperlukan adanya penambahan fasilitas pendidikan SD sederajat hingga SMA sederajat di Kecamatan yang belum terlayani di Kota Blitar untuk memenuhi dan melayani kebutuhan penduduk. Penambahan fasilitas pendidikan SD sederajat yang diperlukan di tiap Kecamatan yang ada di Kota Blitar yaitu Kecamatan Sukorejo 11 unit SD sederajat, Kecamatan Kepanjenkidul 4 unit SD sederajat, dan Kecamatan Sananwetan 11 unit SD sederajat, sedangkan penambahan fasilitas pendidikan SMP sederajat dan SMA sederajat yang diperlukan di Kecamatan Sukorejo dan Sananwetan yaitu di Kecamatan Sukorejo dibutuhkan penambahan 5 unit SMP sederajat dan 4 unit SMA sederajat, sedangkan di Kecamatan Sananwetan dibutuhkan penambahan 2 unit SMP sederajat dan 1 unit SMA sederajat. 
Fasilitas pendidikan jenjang SMP sederajat dan SMA sederajat yang berada di Kecamatan Kepanjenkidul Kota Blitar memiliki nilai daya layan surplus. Fasilitas pendidikan jenjang SMP sederajat yang tingkat pelayanannya surplus dikarenakan memiliki nilai daya layan yang sebesar 1.06 (DL > 1), yang mana jumlah fasilitas SMP sederajat yang tersedia masih kelebihan satu unit. Daya layan fasilitas pendidikan SMA sederajat didapatkan tingkat pelayanannya surplus sebesar 1.27 (DL > 1). Nilai daya layan akan dikatakan surplus apabila nilai lebih dari satu (DL > 1) karena jumlah fasilitas yang tersedia telah mendukung kebutuhan penduduk dan fasilitas pendidikan yang tersedia lebih banyak dibandingkan dengan jumlah fasilitas minimum (Muta'ali, 2015). Hal tersebut dikarenakan fasilitas pendidikan SMA sederajat di Kecamatan Kepanjenkidul masih kelebihan 3 unit. Daya layan fasilitas pendidikan yang surplus ini, maka didapatkan tidak perlunya penambahan fasilitas. Hal ini didukung oleh pernyataan yang mana semakin tinggi daya layan fasilitas maka semakin terlayani penduduk pendukung dalam mendapatkan suatu fasilitas (Baroroh \& Kurniawan, 2018). Hal tersebut nantinya juga menyebabkan tidak akan terjadi kesenjangan fasilitas pendidikan di Kecamatan Kepanjenkidul. Menurut pernyataan Ramadhana \& Prakoso (2018) jika kebutuhan penduduk di suatu wilayah sudah mampu terpenuhi oleh ketersediaan fasilitas pendidikan, maka tidak akan terjadinya kesenjangan antar wilayah satu dengan yang lainnya.

\section{Proyeksi Kebutuhan Fasilitas Pendidikan di Kota Blitar tahun 2030}

Proyeksi kebutuhan fasilitas pendidikan merupakan prediksi jumlah kebutuhan fasilitas pendidikan jenjang SD sederajat, SMP sederajat, dan SMA sederajat yang diprediksi 10 tahun yang akan datang yaitu hingga tahun 2030. Proyeksi ini digunakan untuk mengetahui apakah suatu jenis fasilitas pendidikan di akhir tahun perencanaan masih memadai atau membutuhkan penambahan guna memenuhi kebutuhan penduduk akan fasilitas pendidikan. Penambahan suatu fasilitas ditentukan oleh perkembangan jumlah penduduk di suatu wilayah. Ini didukung pernyataan bahwa penentu dari tingkat pelayanan sentral adalah jumlah penduduk. Oleh sebab itu, menjadi sangat penting fungsi dari pusat sentral, contohnya sebagai pusat pendidikan, perdagangan, pemerintahan, ataupun rekreasi (Suryani, 2015).

Tabel 5. Proyeksi Kebutuhan Fasilitas Pendidikan di Kota Blitar Tahun 2030

\begin{tabular}{|c|c|c|c|c|c|c|c|c|c|}
\hline \multirow{3}{*}{$\begin{array}{c}\text { Kecamat } \\
\text { an }\end{array}$} & \multirow{3}{*}{$\begin{array}{l}\text { Fasilitas } \\
\text { Pelayanan }\end{array}$} & $\begin{array}{c}\text { Jumlah } \\
\text { Pendu } \\
\text { duk } \\
\text { Tahun } \\
2020 \\
(\mathrm{t} 0) \\
\end{array}$ & $\begin{array}{l}\text { Pertumbu } \\
\text { han } \\
\text { Pendudu } \\
\text { k }\end{array}$ & $\begin{array}{c}\text { Proyeksi } \\
\text { Penduduk } \\
\text { tahun } 2030 \\
(\mathrm{t}+10)\end{array}$ & $\begin{array}{c}\text { SPM } \\
\text { (Pendud } \\
\text { uk } \\
\text { Penduku } \\
\text { ng) }\end{array}$ & $\begin{array}{l}\text { Ketersedi } \\
\text { aan } \\
\text { Fasilitas } \\
\text { tahun } \\
2020\end{array}$ & $\begin{array}{l}\text { Proyeksi } \\
\text { Kebutu } \\
\text { han } \\
\text { fasilitas } \\
\text { tahun } \\
2030 \\
\end{array}$ & $\begin{array}{c}\text { Jumlah } \\
\text { Tamba } \\
\text { han } \\
\text { Fasilita } \\
\text { s }\end{array}$ & $\begin{array}{c}\text { Keteran } \\
\text { gan }\end{array}$ \\
\hline & & $\begin{array}{c}\text { data } \\
\text { sekund } \\
\text { er } \\
\end{array}$ & $\begin{array}{c}\text { data } \\
\text { sekunder }\end{array}$ & $\begin{array}{l}\text { pengolahan } \\
\text { data }\end{array}$ & panduan & $\begin{array}{c}\text { data } \\
\text { sekunder }\end{array}$ & $\begin{array}{l}\text { pengola } \\
\text { han data }\end{array}$ & $\begin{array}{c}\text { pengol } \\
\text { ahan } \\
\text { data } \\
\end{array}$ & \\
\hline & & 1 & 2 & $\begin{array}{c}3=1 \mathrm{x} \\
(1+2)^{\wedge}(\mathrm{t} 3-\mathrm{t} 1)\end{array}$ & 4 & 5 & $6=3: 4$ & $7=6-5$ & 8 \\
\hline \multirow[t]{3}{*}{ Sukorejo } & $\begin{array}{l}\mathrm{SD} \\
\text { sederajat }\end{array}$ & 53882 & $0.58 \%$ & 57090 & 1600 & 23 & 36 & 13 & defisit \\
\hline & $\begin{array}{l}\text { SMP } \\
\text { Sederajat }\end{array}$ & 53882 & $0.58 \%$ & 57090 & 4800 & 6 & 12 & 6 & defisit \\
\hline & $\begin{array}{l}\text { SMA } \\
\text { Sederajat }\end{array}$ & 53882 & $0.58 \%$ & 57090 & 4800 & 7 & 12 & 5 & defisit \\
\hline \multirow[t]{3}{*}{$\begin{array}{l}\text { Kepanje } \\
\text { nkidul }\end{array}$} & $\begin{array}{l}\mathrm{SD} \\
\text { sederajat }\end{array}$ & 45395 & $0.39 \%$ & 47197 & 1600 & 24 & 29 & 5 & defisit \\
\hline & $\begin{array}{l}\text { SMP } \\
\text { Sederajat }\end{array}$ & 45395 & $0.39 \%$ & 47197 & 4800 & 10 & 10 & 0 & cukup \\
\hline & $\begin{array}{l}\text { SMA } \\
\text { Sederajat }\end{array}$ & 45395 & $0.39 \%$ & 47197 & 4800 & 12 & 10 & -2 & surplus \\
\hline \multirow[t]{2}{*}{$\begin{array}{l}\text { Sananwe } \\
\tan \end{array}$} & $\begin{array}{l}\text { SD } \\
\text { sederajat }\end{array}$ & 58632 & $0.47 \%$ & 61447 & 1600 & 26 & 38 & 12 & defisit \\
\hline & SMP & 58632 & $0.47 \%$ & 61447 & 4800 & 10 & 13 & 3 & defisit \\
\hline
\end{tabular}


Sederajat

SMA

Sederajat

$58632 \quad 0.47 \%$

61447

4800

11

13

2

defisit

Sumber: hasil analisis peneliti, 2021.

Proyeksi penduduk di Kota Blitar yaitu Kecamatan Sukorejo, Kepanjenkidul, dan Sananwetan yang diprediksi 10 tahun yang akan datang yaitu hingga tahun 2030 mendatang, jumlah penduduk dapat diperkirakan mencapai 57.090 jiwa untuk Kecamatan Sukorejo, 47.197 jiwa untuk Kecamatan Kepanjenkidul dan 61.447 jiwa untuk Kecamatan Sananwetan. Berdasarkan jumlah penduduk di tiga Kecamatan tersebut dapat dipastikan kebutuhan fasilitas pendidikan SD sederajat di tahun 2030 masih sangat kurang dan belum mampu mendukung kebutuhan penduduk dengan jumlah fasilitas pendidikan yang tersedia saat ini sehingga dibutuhkan penambahan fasilitas. Penambahan fasilitas pendidikan SD sederajat yang diperlukan pada tahun 2030 mendatang adalah 13 unit SD sederajat di Kecamatan Sukorejo, 5 unit SD sederajat di Kecamatan Kepanjenkidul, dan 12 unit SD sederajat di Kecamatan Sananwetan.

Kebutuhan fasilitas pendidikan pada jenjang SMP sederajat di tiga Kecamatan Kota Blitar hanya fasilitas pendidikan SMP sederajat di Kecamatan Kepanjenkidul yang sudah mampu mencukupi kebutuhan penduduk, sedangkan di Kecamatan Sukorejo dan Sananwetan masih membutuhkan penambahan fasilitas. Penambahan Fasilitas pendidikan SMP sederajat yang diperlukan yaitu 6 unit SMP sederajat di Kecamatan Sukorejo dan 3 unit SMP sederajat di Kecamatan Sananwetan. Berdasarkan Muta'ali (2015) meningkatnya tuntutan kebutuhan fasilitas pendidikan dipengaruhi oleh jumlah penduduk, sehingga jumlah penduduk yang semakin bertambah maka kebutuhan fasilitas juga bertambah. Hal itu juga sesuai dengan Baroroh \& Kurniawan (2018) jumlah penduduk yang meningkat dapat mempengaruhi meningkatnya kebutuhan sarana dan prasarana pendidikan yaitu fasilitas pendidikan.

Kebutuhan fasilitas pendidikan jenjang SMA sederajat di tiga kecamatan Kota Blitar hingga tahun 2030 berdasarkan jumlah penduduk yang ada, hanya Kecamatan Kepanjenkidul yang tidak memerlukan penambahan fasilitas pendidikan SMA sederajat karena masih mampu mencukupi kebutuhan penduduk yang ada dan masih kelebihan dua unit fasilitas, sedangkan Kecamatan Sukorejo dan Sananwetan masih belum mencukupi kebutuhan penduduk dan masih diperlukan penambahan fasilitas. Penambahan fasilitas pendidikan SMA sederajat yang dibutuhkan yaitu 5 unit SMA sederajat di Kecamatan Sukorejo dan 2 unit SMA sederajat di Kecamatan Sananwetan. Oleh karena itu, fasilitas pendidikan di Kota Blitar yang masih belum mencukupi kebutuhan penduduk atau masih kurang perlu adanya kebijakan dari pemerintah dalam penambahan fasilitas pendidikan SD sederajat hingga SMA sederajat guna meningkatkan kualitas pendidikan secara optimal. Hal tersebut juga merupakan upaya untuk meningkatkan Sumber Daya Manusia (SDM) di tiap kecamatan Kota Blitar. Ketersediaan fasilitas dasar seperti pendidikan yang memadai sesuai dengan jumlah pertumbuhan penduduk menjamin pembangunan manusia di suatu daerah. Hal ini sesuai dengan riset Gewab, Malik, \& Karongkong (2015) yang mana ketersediaan fasilitas pendidikan dapat meningkatkan kualitas pendidikan serta memberikan dampak untuk meningkatkan kualitas sumber daya manusia. Hal tersebut juga sesuai dengan Latuconsina (2017) salah satu aspek yang berpengaruh terhadap indeks pembangunan manusia adalah aspek pendidikan yang meliputi sarana pendidikan. Oleh karena itu, semakin mencukupinya fasilitas pendidikan di suatu wilayah maka indeks pembangunan manusia juga semakin tinggi atau baik.

\section{SIMPULAN}

Daya layan fasilitas pendidikan tingkat SD sederajat di tiap kecamatan Kota Blitar yaitu Kecamatan Sukorejo, Kepanjenkidul, dan Sananwetan memiliki tingkat pelayanan deficit. Hal ini disebabkan karena jumlah fasilitas SD sederajat yang tersedia belum mampu mendukung kebutuhan penduduk, daya layan fasilitas pendidikan tingkat SMP sederajat di Kota Blitar yang memiliki tingkat pelayanan surplus hanya di Kecamatan Kepanjenkidul karena sudah mampu mendukung kebutuhan penduduk dan masih kelebihan 1 unit SMP sederajat, sedangkan fasilitas pendidikan SMP sederajat di Kecamatan Sukorejo dan Sananwetan memiliki tingkat pelayanan defisit karena masih belum mampu mendukung kebutuhan penduduk. Daya layan fasilitas pendidikan tingkat SMA sederajat di Kota Blitar 
yang memiliki tingkat pelayanan surplus hanya di Kecamatan Kepanjenkidul karena fasilitas SMA sederajat yang tersedia sudah mampu mendukung kebutuhan penduduk dan masih kelebihan 3 unit, sedangkan fasilitas pendidikan SMA sederajat di Kecamatan Sukorejo dan Sananwetan memiliki tingkat pelayanan defisit karena belum mampu mendukung kebutuhan penduduk.

Proyeksi kebutuhan fasilitas pendidikan tingkat SD sederajat di tiap Kecamatan Kota Blitar yaitu Kecamatan Sukorejo, Kepanjenkidul, dan Sananwetan masih diperlukan penambahan fasilitas pendidikan SD sederajat karena tidak sebanding dengan laju pertumbuhan penduduk. Proyeksi kebutuhan fasilitas pendidikan tingkat SMP sederajat di Kota Blitar hanya Kecamatan Kepanjenkidul yang sudah memenuhi sehingga tidak diperlukan penambahan fasilitas, sedangkan fasilitas SMP sederajat di Kecamatan Sukorejo dan Sananwetan masih diperlukan penambahan fasilitas karena tidak sebanding dengan laju pertumbuhan penduduk. Proyeksi kebutuhan fasilitas pendidikan tingkat SMA sederajat di Kota Blitar hanya Kecamatan Kepanjenkidul yang masih mencukupi dan memenuhi dan tidak diperlukan penambahan fasilitas pendidikan, sedangkan fasilitas pendidikan SMA sederajat di Kecamatan Sukorejo dan Sananwetan masih diperlukan penambahan fasilitas pendidikan karena tidak sebanding dengan laju pertumbuhan penduduk.

\section{DAFTAR PUSTAKA}

Adniyah, H., \& Putra, A. M. (2017). Strategi Buruh Tani dalam Memenuhi Kebutuhan Pendidikan Anak di Desa Karang Baru Batu Rente Kecamatan Wanasaba Kabupaten Lombok Timur. Geodika: Jurnal Kajian Ilmu dan Pendidikan Geografi, 1(2), 1-6.

Baroroh, S., \& Kurniawan, A. (2018). Daya Layan Fasilitas Pendidikan SLTA Pasca Pemekaran Kabupaten Pringsewu Provinsi Lampung. Jurnal Bumi Indonesia, 7(2), 1-10.

BPS Kota Blitar. (2020). Kota Blitar Dalam Angka 2020. Kota Blitar: BPS Kota Bitar.

BPS Kota Blitar. (2020). Statistik Daerah Kota Blitar. Kota Blitar: Badan Pusat Statistik Kota Blitar.

BPS. (2015). Laporan Eksekutif Statistik Pendidikan Provinsi Jawa Timur 2015. surabaya: Badan Pusat Satistik Provinsi Jawa Timur.

BPS. (2019). Potret Pendidikan Indonesia Statistik Pendidikan 2019. Jakarta: Badan Pusat Statistik Jakarta.

Gewab, H. C., Malik, A., \& Karongkong, H. H. (2015). Analisis Kebutuhan dan Sebaran Fasilitas Pendidikan Tingkat SMP dan SMA di Kabupaten Tambrauw. Spasial, 2(3), 43-52.

Henlita, S., \& Handayeni, K. D. (2013). Tingkat Pelayanan Fasilitas Pendidikan Sekolah Menengah Tingkat Atas di Kabupaten Sidoarjo. Jurnal Teknik Pomits, 2(2), 197-202.

Ibrahim, J. T. (2020). Metode Penelitian Sosial Ekonomi Pertanian. Malang: UMM Press.

Inkiriwang, R. R., Singal, R., \& Roeroe, J. V. (2020). Kewajiban Negara dalam Penyediaan Fasilitas Pendidikan Kepada Masyarakat Menurut Undang-Undang Nomor 20 Tahun 2003 Tentang Sistem Pendidikan Nasional. Lex Privatum, 2(8), 143-153.

Junianto, \& Lumbantoruan, W. (2013). Analisis Ketersediaan Fasilitas Pelayanan Sosial Ekonomi di Kecamatan Batang Kuis Kabupaten Deli Serdang. Jurnal Geografi, 5(1), 149-155.

Latief, H., Rohmat, D., \& Ningrum, E. (2014). Pengaruh Pembelajaran Kontekstual Terhadap Hasil Belajar (Studi Eksperimen pada Mata Pelajaran Geografi Kelas VII di SMPN 4 Padalarang). Jurnal GEA, 14(2), 14-28.

Latuconsina, Z. M. (2017). Analisis Faktor-faktor yang Mempengaruhi Indeks Pembangunan Manusia di Kabupaten Malang Berbasis Pendekatan Perwilayahan dan Regresi Panel. Jurnal Perencanaan Pembangunan Wilayah dan Perdesaan, 1(2), 202-216.

Muta'ali, L. (2015). Teknik Analisis Regional Untuk Perencanaan Wilayah, Tata Ruang dan Lingkungan. Yogyakarta: Badan Penerbit Fakultas Geografi. 
Ningsih, S., Ernawati, \& Nofrion. (2018). Analisis Ketersediaan dan Penggunaan Fasilitas Pendidikan Sekolah Menengah Atas dan Madrasah Aliyah di Kecamatan Koto Tangah Kota Padang. Jurnal Buana, 2(4), 163-175.

Nurlaela, A. (2014). Peranan Lingkungan Sebagai Sumber Pembelajaran Geografi dalam Menumbuhkan Sikap dan Perilaku Keruangan Peserta Didik. Jurnal GEA, 14(1), 40-48.

Olilingo, F. Z. (2017). Potensi Investasi di Provinsi Gorontalo. Yogyakarta: Deepublish.

Prianto, D. A., \& Putri, T. H. (2017). Pengaruh Ketersediaan Fasilitas Belajar, Dukungan Orang Tua yang Dirasakan Terhadap Motivasi dan Prestasi Belajar Siswa SMA PGRI Ngimbang Lamongan. Jurnal Pendidikan Ekonomi, Kewirausahaan, Bisnis, dan Manajemen (JPEKBM), 1(2), 13-38.

Ramadhana, A. N., \& Prakoso, B. S. (2018). Analisis Ketersediaan dan Keterjangkauan Fasilitas Pendidikan Jenjang Sekolah Dasar (SD) dan Sekolah Menengah Pertama (SMP) di Kota Metro. Jurnal Bumi Indonesia, 7(3), 1-10.

Sadali, M. I., Intizhar, F., \& Aisyah. (2017). Analisis Ketersediaan Fasilitas Sosial di Kabupaten Banjarnegara, sebagai Pendukung Kondisi Darurat Bencana dan Pengembangan Wilayah. Media Komunikasi Geografi, 18(2), 128-145.

Siyoto, S., \& Sodik, A. (2015). Dasar Metodologi Penelitian. Yogyakarta: Literasi Media Publishing.

SNI 03-1733-2004 Tentang Tata Cara Perencanaan Lingkungan Perumahan di Perkotaan.

Sugiyono. (2017). Metode Penelitian Kuantitatif, Kualitatif, R\&D. Bandung: Alfabeta.

Suryani, Y. (2015). Teori Lokasi dalam Penentuan Pembangunan Lokasi Pasar Tradisional (Telaah Studi Literatur). Padang: Seminar Nasional Ekonomi Manajemen dan Akuntansi (SNEMA) Fakultas Ekonomi Universitas Negeri Padang.

Suryani. (2017). Manajemen Sarana Prasarana dan Prestasi Belajar Peserta didik. Jurnal Kependidikan Islam, 7(2), 157-174.

Tahir, M. A., \& Nahdatunnisa. (2020). Analisis Ketersediaan dan Pemenuhan Kebutuhan Prasarana dan Sarana Permukiman di Kawasan Perkotaan. Jurnal Malige Arsitektur, 2(1), 20-29.

Tarigan, R. (2006). Perencanaan Pembangunan Wilayah. Jakarta: PT Bumi Aksara.

Uang, O. L., Rengkung, M. M., \& Sembel, A. S. (2017). Evaluasi Ketersediaan Fasilitas Pendidikan SLTP di Kecamatan Mapanget. Spasial, 4(3), 234-244.

Umasangadji, M. S. (2015). Analisis Kebutuhan dan Penempatan Prasarana-Sarana Fasilitas Pendidikan di Kecamatan Wori. Spasial, 2(3), 170-181. 